\title{
Intellectual property rights, $R \& D$ expenditures, and high-tech exports in the EU transition economies
}

\author{
Yilmaz Bayar \\ Department of Economics, Usak University \\ Turkey \\ yilmaz.bayar@usak.edu.tr
}

\section{Rita Remeikienè}

Faculty of Economics and Business, Mykolas Romeris University

Lithuania

rita.remeikiene@mmuni.eu

\section{Ligita Gasparènienè}

Faculty of Economics and Business, Mykolas Romeris University

Lithuania

ligitagaspareniene@mmuni.eu

Abstract. Several countries have begun to follow export-led growth strategy along with the accelerating liberalization and globalization processes. One of the key goals behind this strategy is to enhance the share of high-tech exports with relatively much higher value added in exports. This study investigates the effect of intellectual property rights and $\mathrm{R} \& \mathrm{D}$ expenditures together with foreign direct investment inflows on high-tech exports of the EU transition economies over the 2000-2016 period through panel data analysis. The methods of this research include systematic and comparative literature analysis, and panel data analysis. The analyses reveal that intellectual property rights and R\&D expenditures positively affect high-tech export, while FDI negatively affects high-tech export in the long run.

Keywords: Intellectual Property Rights, R\&D Expenditures, FDI inflows, HighTech Exports, Panel Data Analysis.

JEL Classification: C23, F14, O30, O40 


\section{INTRODUCTION}

Development of high-tech export is recognized as an important factor of sustainable national and global economic growth. High-tech industries not only leverage innovation and technological advancement, but they also significantly contribute to higher productivity of other industries. Over the last 25 years, the rate of high-tech export in total manufacturing export has considerably increased (Falk, 2009), and high-tech export has become the fastest growing segment of international trade. At a national level, the ability to export high-tech products and services reflects both country's knowledge base and its capability to apply this knowledge.

Scientific literature provides strong evidence that the development of high-tech export can greatly stimulate the growth of developing and transition economies, as it may serve as a proxy to liberalize these economies (Dzemydaite, Dzemyda, 2012; Vasa, 2012), promote foreign direct investment (FDI) (Kabaklarli et al., 2018) and raise technological intensity of local export bases (Srholec, 2005). For this reason, problems and determinants of high-tech export in developing and transition economies have recently become relevant issues in scientific research.

Development of high-tech export can be promoted by different factors, but technological infrastructure, national orientation, socioeconomic infrastructure and productive capacity are revealed to be the most considerable ones (Taplin, Novak, 2010). National orientation incorporates the vision for innovation, while socioeconomic infrastructure covers capital mobility and FDI promotion. On the other side, technological infrastructure encompasses $R \& D$ outputs to the market and the quantity of scientists in $\mathrm{R} \& \mathrm{D}$, while productive capacity comprises labor supply and the quantity of indigenous firms in high-tech. As the aforementioned factors are driven by the expansion of $R \& D$ expenditures, intellectual property rights and FDI inflows, it can be stated that intellectual property rights, R\&D expenditures, and FDI inflows generate the main potential of high-tech export.

The determinants underlying high-tech export have thus far earned sufficient scientific attention: the impact of intellectual property rights was researched by Ivus (2008), Hwang et al. (2016), Mrad (2017), Bakirci et al. (2017), Lin and Linkoln (2018), etc.; the impact of R\&D expenditures was analyzed by Lall (2000), Guravsar Gokce et al. (2010), Xing (2012), Sandu and Ciocanel (2014), Ustabas \& Ersin (2016), etc.; the impact of FDI inflows was studied by Gokmen \& Turen (2013), Mitic \& Ivic (2016), Bakirci et al. (2017), etc., but scientific literature still lacks studies with a complex interpretation of the effects of intellectual property rights, R\&D expenditures and FDI inflows on high-tech export, especially in transition economies. Besides, as different studies provide contradictory results, and the real economic effects of intellectual property rights, R\&D expenditures and FDI inflows may vary depending on the level of a country's development, a deeper insight on the impact of intellectual property rights, $R \& D$ expenditures, and FDI inflows on high-tech export in transition economies is still a topical issue.

The main purpose of this article is to investigate the effect of intellectual property rights and R\&D expenditures together with FDI inflows on high-technology export in the EU transition economies over the 2000-2016 period. The defined purpose was detailed into the following objectives: 1) to review previous findings on the effects of intellectual property rights, R\&D expenditures, and FDI inflows on high-tech exports; 2) to select and substantiate the research methodology; 2) to introduce the results of the empirical research revealing the effect of intellectual property rights, R\&D expenditures, and FDI inflows on high-tech exports in the EU transition economies over the 2000-2016 period. The methods of the research include systematic and comparative literature analysis, and panel data analysis. 


\section{LITERATURE REVIEW}

A great number of countries have shifted to the export-oriented growth from import substituting industrialization during the past four decades. One of the main factors behind the strategy is to increase the share of high-tech goods with relatively higher value-added in the export. In this regard, the determinants of high-tech exports have been widely researched by scholars to design and implement the right policies and many institutional, legal, economic, social, political, and cultural factors have been documented in the relevant literature (e.g. Tebaldi, 2011; Mehrara et al., 2017). In this study, the effect of intellectual property rights, R\&D expenditures, and FDI inflows on high-tech exports would be researched to see the results of the two main factors including property rights and R\&D expenditures followed by many countries.

The studies of the effects on intellectual property rights on high-tech export provide mixed results, which, as it was noted by Mrad (2017), to a large extent depend on the researchers' assumptions about innovation and imitation. Ivus (2008) found out that stronger intellectual property rights (IPRs) added nearly $\$ 50$ billion US dollars to the annual value of high-tech export in developed countries, and the increase in the export was mainly achieved by the quantity, not the price. Positive effect on IPRs protection on high-tech export in developing economies were also confirmed by Liu \& Lin (2005), Mrad (2017), and the others.

Hwang et al.'s (2016) study, however, showed that the economic effect on IPRs protection may vary depending on the level of a country's development: as the tighter IPRs protection reduces the variety of intermediate products and raises a final product's costs, the relationship between IPRs protection and high-tech export in developing economies is U-shaped. Bakirci et al.'s (2017) and Lin \& Linkoln's (2018) findings support the view that tighter IPRs protection in developing economies leads to greater import variety rather than to high-tech export development, since advanced technology products contain many imported components, and developing economies are heavily reliant on import to obtain the latest technologies.

R\&D intensity is recognized as the main input factor in the innovation process (Falk, 2009). The econometric analysis, conducted by Sandu \& Ciocanel (2014), confirmed the existence of the causal relationship between $\mathrm{R} \& \mathrm{D}$ volumes and high-tech export in the $\mathrm{EU}$ : it was revealed that the $\mathrm{R} \& \mathrm{D}$ expenditure positively correlates with the high-tech export, although some variance in the strength of this correlation can be observed at a country level. The results also revealed that private $R \& D$ expenditure affects high-tech export rather than public R\&D expenditure. Positive relationship between the volume of $\mathrm{R} \& \mathrm{D}$ expenditure and the level of high-tech export was also detected by Belay (2005), Guravsar Gokce et al. (2010), Ustabas \& Ersin (2016), and many others. Nevertheless, some studies provide opposite results. For instance, Lall (2000) revealed an insignificant interaction between R\&D expenditures and high-tech export in Turkey. The author presumes that such results are expected keeping in mind the weak technological development dynamics in the country. Xing's (2012) study revealed that the development of high-tech export in China (a developing economy) is determined by the import of structural parts used for the assembly of high-tech rather than by intensification of R\&D expenditures. Bakirci et al. (2017) revealed a one-way causal interaction from fixed capital investment and FDI flows to high-tech export.

Technological advancement can be attained through technology transfer by the channel of inward foreign direct investment. As it was noted by Bakirci et al. (2017), FDI inflows may make a positive contribution to technological development through enhancing the physical capital stock and allowing the countries to obtain the new production methods and organizational forms through FDI inflows. However, the interaction between FDI inflows and technological progress can be negative, depending on type of FDI inflows, human capital quality, and economic development level of the countries. Considering 
high-tech as a longitudinal function of a country's level of inward FDI and applying panel cointegration method, Gokmen \& Turen (2013) determined that FDI affected the high-tech export positively. Their panel causality test revealed a long-run Granger causality running from FDI to high-tech export. Some other studies, however, showed that the interaction between FDI and high-tech export may vary in developed and least developed economies. For instance, Bakirci et al. (2017) found out that the influence of FDI inflows on high-tech exports is generally positive in the most developed economies, but negative in the least developed ones (i.e. the authors established the positive relationship between FDI inflows and high-tech export in developed countries and the inverse relationship between the above-mentioned variables in least developed countries).

Summarizing, although tight intellectual property rights, increasing volumes of $\mathrm{R} \& \mathrm{D}$ expenditures and intensive inflows of FDI may promote high-tech exports, the real economic effects may vary depending on the level of a country's development and the impact of other factors (e.g. the dynamics of national technological development, origin of the structural parts used for the assembly of high-tech, etc.). Since previous studies provide contradictory findings, a deeper insight in the impact of intellectual property rights, R\&D expenditures and FDI inflows on high-tech export in transition economies is still relevant.

\section{METHODOLOGY}

The study researches the effect of intellectual property rights, R\&D expenditures, and FDI inflows on the high-tech exports in transition economies of EU for the duration of 2000-2016 through panel data analysis.

\subsection{Data}

In the econometric analysis, high technology export was proxied by high-technology export as a percentage of manufactured export. On the other hand, intellectual property rights were represented by the protection of property rights index of Fraser Institute (2019) and takes values between 1 and 10, where higher values represent better protection of security rights. R\&D expenditures are proxied by capital and current expenditures on basic and applied research, and experimental progress in the sectors of government, business, higher education and private non-profit. Lastly, FDI inflows were represented by FDI net inflows. The protection of property rights index was extracted from database of Fraser Institute (2019) and the variables of high-technology exports, whereas R\&D expenditures and FDI inflows were provided from database of World Bank. All the series were annual, and the study duration was specified as 2000-2016, taking cognizance of data availability.

Table 1

Dataset summary

\begin{tabular}{|l|l|l|}
\hline \multicolumn{1}{|c|}{ Variables } & \multicolumn{1}{|c|}{ Variable Definitions } & \multicolumn{1}{|c|}{ Source } \\
\hline HIGHTECH & $\begin{array}{l}\text { High technology exports (\% of manufactured } \\
\text { exports) }\end{array}$ & World Bank (2019a) \\
\hline PRIGHTS & Protection of property rights index & Fraser Institute (2019) \\
\hline RD & $\begin{array}{l}\text { Research and development expenditure }(\% \text { of } \\
\text { GDP) }\end{array}$ & World Bank (2019b) \\
\hline FDI & Foreign direct investment, net inflows (\% of GDP) & World Bank (2019c) \\
\hline
\end{tabular}

Source: compiled by the authors 
The sample of the research was formed cooperating with Bulgaria, Croatia, Czech Republic, Estonia, Hungary, Latvia, Lithuania, Poland, Romania, Slovak Republic, and Slovenia. The statistical packages of Stata 14.0, EViews 10.0 and Gauss 10.0 were employed for the econometric analysis. The ratio of hightech export in manufactured export was nearly $9.53 \%$ on average, the mean value of property right's protection was about 5.2, and the average values of R\&D expenditures and FDI inflows were respectively about $0.92 \%$ and $5.46 \%$ of GDP in the sample.

Table 2

Summary and descriptive statistics of the dataset

\begin{tabular}{|l|c|c|c|c|c|}
\hline Variables & Obs & Mean & Std. Dev. & Min & Max \\
\hline HIGHTECH & 187 & 9.53 & 5.64 & 2.87 & 29.93 \\
\hline PRIGHT & 187 & 5.20 & 1.13 & 2.64 & 7.95 \\
\hline RD & 187 & 0.92 & 0.48 & 0.36 & 2.58 \\
\hline FDI & 187 & 5.46 & 7.44 & -15.98 & 55.49 \\
\hline
\end{tabular}

Source: compiled by the authors

We expect the variables of property rights and $R \& D$ expenditures to affect the high technology exports positively considering the relevant theoretical and empirical literature (Ivus, 2008; Mrad, 2017; Belay, 2005; Guravsar Gokce et al., 2010; Ustabas \& Ersin, 2016). Nevertheless, the effect of FDI inflows on the high technology export can be negative or positive based on the general level of a country's economic and technological development, and human capital quality (Bakirci et al., 2017).

\subsection{Econometric methodology}

The short and long run interaction among high technology export, property rights, R\&D expenditures, and FDI inflows were analyzed by Westerlund \& Edgerton (2007) LM (Lagrange multiplier) cointegration test and causality test of Dumitrescu \& Hurlin (2012). The Westerlund \& Edgerton (2007) LM cointegration test rests on the LM test by McCkoskey and Kao (1998) and takes cognizance of crosssection dependence in the countries. The cointegration test statistic $\left(L M_{N}^{+}\right)$is figured out as follows:

$$
L M_{N}^{+}=\frac{1}{N T^{2}} \sum_{i=1}^{N} \sum_{t=1}^{T} \hat{w}_{i}^{-2} s_{i t}^{2}(1)
$$

The partial sum of error terms $\left(s_{i t}^{2}\right)$ and long-term variances $\left(\hat{w}_{i}^{-2}\right)$ are produced from the cointegration model estimated with FMOLS (fully modified ordinary least squares) model. The null hypothesis supporting the availability of the cointegration is tested by $L M_{N}^{+}$, and critical values generated by the bootstrap method were used in the event of cross-sectional dependence. Furthermore, the test gives robust consequences in case of small samples due to the implementation of Monte Carlo simulations.

The cointegration coefficients are estimated with the AMG (augmented mean group) estimator of Eberhardt and Teal (2010) taking cognizance of the availability of cross-sectional dependence, and heterogeneity. The AMG estimator yields both individual and panel cointegration coefficients, but it should be employed in case all the series are I(1). The AMG estimator gives more reliable results than CCE (Common Corelated Effects) estimator of Pesaran (2006), because the test calculates the panel cointegration coefficients by weighting the arithmetic averages of the cross-sections' coefficients. Furthermore, panel AMG estimator also takes cognizance of common factors and dynamic effects in the series and yields efficient results for the unbalanced panels. Also, it can be used in case of endogeneity 
problem resulting from the error terms (Eberhardt \& Bond, 2009). Panel AMG estimator separates the variables in the following way:

$$
\begin{gathered}
y_{i t}=\beta_{i}^{2} x_{i t}+u_{i t} ; \\
u_{i t}=\alpha_{i}+\lambda_{i}^{2} f_{t}+\varepsilon_{i t} \quad(i=1 \ldots . . ., t=1 \ldots ., m=1 \ldots . k) \\
x_{m i t}=\pi_{m i}+\delta_{m i}^{i} g_{m t}+\rho_{1 m i} f_{1 m t}+\cdots .+\rho_{n m i} f_{n m t}+v_{i t} \\
f_{t}=\tau^{1} f_{t-1}+\varepsilon_{i t} \text { ve } g_{t}=\Psi^{2} g_{t-1}+\Omega_{i t}
\end{gathered}
$$

Where $x_{i t}$ is vector of observable covariates and $f_{t}$ and $g_{t}$ are unobserved common factors and $\lambda_{i s}$ are country-specific factor loadings.

Lastly, causal interaction was researched with Dumitrescu and Hurlin (2012) causality test based upon vector autoregression. The test takes cognizance of heterogeneity, but the test results are robust results even under the cross-sectional dependence. The $Z$ hnc $\left(Z_{N, T}^{H N C}\right)$ test statistics having asymptotic distribution should be taken notice in case of $\mathrm{T}>\mathrm{N}$, and Ztild $\left(Z_{N}^{H N C}\right)$ test statistics having semiasymptotic distribution should be taken in consideration in case of $\mathrm{N}>\mathrm{T}$. The aforementioned statistics are calculated as follows:

$$
\begin{gathered}
W_{N, T}^{H N C}=\frac{1}{N} \sum_{i=1}^{N} W_{i, T} \quad\left(W_{i, T} \text { are individual Wald statistics }\right)(6) \\
Z_{N, T}^{H N C}=\sqrt{\frac{N}{2 K}\left(W_{N, T}^{H N C}-K\right) \quad T, N \rightarrow \infty, N(0,1) \quad(7)} \\
Z_{N}^{H N C}=\frac{\sqrt{N}\left[W_{N, T}^{H N C}-N^{-1} \sum_{i=1}^{N} E\left(W_{i, T}\right)\right]}{\sqrt{N^{-1} \sum_{i=1}^{N} \operatorname{Var}\left(W_{i, T}\right)}} \quad N \rightarrow \infty, N(0,1)(8)
\end{gathered}
$$

Materials and Methods should be described with sufficient details to allow others to replicate and build on published results. Please note that publication of your manuscript implicates that you must make all materials, data, computer code, and protocols associated with the publication available to readers. Please disclose at the submission stage any restrictions on the availability of materials or information. New methods and protocols should be described in detail while well-established methods can be briefly described and appropriately cited.

\section{EMPIRICAL RESULTS AND DISCUSSION}

The specification of cross-sectional dependence and heterogeneity's presence among the crosssections is very important for choosing the correct econometric tests of unit root, cointegration and causality tests. For this reason, Breusch \& Pagan's (1980) LM test, Pesaran's (2004) LM CD test, and the $L M_{\text {adj }}$, test of Pesaran et al. (2008) utilized to test the cross-section dependence, taking into consideration the dataset's characteristics. The test results are presented in Table 3 and revealed the presence of a crosssectional dependence among the series. As a result, second-generation unit root and cointegration tests would be utilized to check for the existence of the unit root and cointegration relations. 
Cross-sectional dependence tests' results

\begin{tabular}{|l|c|c|}
\hline Test & Test statistic & Prob. \\
\hline LM & 103.1 & 0.0001 \\
\hline LM adj* & 7.393 & 0.0000 \\
\hline LM CD $^{*}$ & 2.65 & 0.0080 \\
\hline
\end{tabular}

*two-sided test

Source: compiled by the authors

Secondly, the cointegration coefficients' homogeneity was checked by using the homogeneity tests of Pesaran and Yamagata (2008), and the test results are shown in Table 4. The null hypothesis in favor of homogeneity was rejected, and thus the cointegration coefficients were revealed as heterogeneous.

Table 4

Homogeneity tests' results

\begin{tabular}{|l|c|c|}
\hline Test & Test statistic & Prob. \\
\hline$\tilde{\Delta}$ & 6.455 & 0.000 \\
\hline$\tilde{\Delta}_{\text {adj. }}$ & 7.596 & 0.000 \\
\hline
\end{tabular}

Source: compiled by the authors

The presence of a unit root in the panel data was questioned with the CIPS (Cross-Sectional IPS (ImPesaran-Shin, 2003)) unit root test of Pesaran (2007) while taking cognizance of the presence of crosssectional dependence. The test consequences are shown in Table 5 . The test consequences revealed that all the series had unit root at their level, but were found to be stationary after first-differentiating.

Table 5

CIPS unit root test's results

\begin{tabular}{|l|c|c|c|c|}
\hline \multirow{2}{*}{ Variables } & \multicolumn{2}{|c|}{ Constant } & \multicolumn{2}{c|}{ Constant+Trend } \\
\cline { 2 - 5 } & Zt-bar & p-value & Zt-bar & p-value \\
\hline HIGHTECH & -1.996 & 0.123 & -0.393 & 0.347 \\
\hline d(HIGHTECH) & -4.038 & 0.000 & 2.557 & 0.005 \\
\hline PRIGHT & 0.026 & 0.510 & -1.172 & 0.121 \\
\hline d(PRIGHT) & -6.028 & 0.000 & -4.074 & 0.000 \\
\hline RD & -1.583 & 0.157 & 0.401 & 0.656 \\
\hline d(RD) & -1.969 & 0.024 & -0.896 & 0.085 \\
\hline FDI & -0.715 & 0.237 & -0.468 & 0.320 \\
\hline $\mathrm{d}($ FDI $)$ & -4.636 & 0.000 & -3.058 & 0.001 \\
\hline
\end{tabular}

Source: compiled by the authors

The cointegration relationship among the series was examined with Westerlund \& Edgerton's (2007) LM boostrap cointegration test, while taking into consideration the cross-sectional dependence and heterogeneity among the series. The test consequences are shown in Table 6 . The null hypothesis in favor of cointegration relationship presence was rejected under cross-sectional independence, but the null hypothesis was accepted under cross-sectional dependence. The bootstrap probability figures were used 
due to the cross-sectional dependence between the series, and we revealed that the series had a cointegration relationship.

Table 6

Westerlund \& Edgerton (2007) LM Boostrap cointegration test results

\begin{tabular}{|c|c|c|c|c|c|c|}
\hline \multirow{3}{*}{$L M_{N}^{+}$} & \multicolumn{3}{|c|}{ Constant } & \multicolumn{3}{c|}{ Constant+Trend } \\
\cline { 2 - 7 } & $\begin{array}{c}\text { Test } \\
\text { statistic }\end{array}$ & $\begin{array}{c}\text { Asymptotic p- } \\
\text { value }\end{array}$ & $\begin{array}{c}\text { Bootstrap p- } \\
\text { value }\end{array}$ & Test statistic & $\begin{array}{c}\text { Asymptotic p- } \\
\text { value }\end{array}$ & Bootstrap p-value \\
\cline { 2 - 7 } & 7.418 & 0.590 & 0.000 & 10.809 & 0.955 & 0.000 \\
\hline
\end{tabular}

The cointegration coefficients were forecast by the AMG estimator of Eberhardt \& Teal (2010) taking notice of the heterogeneity and cross-sectional dependence. The test consequences are shown in Table 7. The panel cointegration coefficients revealed that both intellectual property rights and R\&D expenditures affects the high technology export positively, while FDI inflows negatively affect the high technology export in overall panel. However, the effect on R\&D expenditures on high technology export is far higher rather than the effects on property rights and FDI inflows are.

On the other hand, the individual cointegration coefficients disclosed that property rights positively affected the high technology exports in Bulgaria, Estonia, Hungary, Lithuania, Poland, and Slovak Republic. However, R\&D expenditures had a positive influence on high technology exports in Croatia, Czech Republic, Hungary, Latvia, Lithuania, Poland, Romania, and Slovak Republic. Lastly, FDI inflows negatively affected high technology exports in Bulgaria, Czech Republic, Hungary, Latvia, Romania, and Slovak Republic.

Table 7

Estimation of cointegration coefficients

\begin{tabular}{|c|c|c|c|}
\hline Country & PRIGHT & RD & FDI \\
\hline Bulgaria & $2.071376(0.0006)$ & $0.894526(0.6892)$ & $-0.085323(0.0642)$ \\
\hline Croatia & $-0.459543(0.3597)$ & $8.707568(0.0597)$ & $-0.125676(0.2787)$ \\
\hline Czech Republic & $-0.651051(0.2416)$ & $1.750156(0.0606)$ & $-0.265938(0.0677)$ \\
\hline Estonia & $3.728191(0.0172)$ & $0.038158(0.9868)$ & $0.044338(0.8075)$ \\
\hline Hungary & $1.251166(0.0384)$ & $1.417834(0.0003)$ & $-0.074045(0.0061)$ \\
\hline Latvia & $1.026587(0.2722)$ & $25.961950(0.0054)$ & $-1.018074(0.0092)$ \\
\hline Lithuania & $1.452189(0.0010)$ & $10.130465(0.0059)$ & $-0.316788(0.1209)$ \\
\hline Poland & $0.653921(0.0003)$ & $10.780763(0.0000)$ & $-0.058418(0.3577)$ \\
\hline Romania & $0.514016(0.4317)$ & $17.135901(0.0978)$ & $-0.582793(0.0061)$ \\
\hline Slovak Republic & $1.505691(0.0019)$ & $9.741465(0.0001)$ & $-0.283471(0.0164)$ \\
\hline Slovenia & $-0.581879(0.2107)$ & $0.269989(0.5198)$ & $0.006683(0.9209)$ \\
\hline Panel & $0.277662(0.0981)$ & $6.090283(0.0000)$ & $-0.250864(0.0000)$ \\
\hline
\end{tabular}

Source: compiled by the authors

In the last stage of the econometric analysis, the causal interaction among intellectual property rights, R\&D expenditures, FDI inflows and high technology export was examined with Dumitrescu and Hurlin (2012) causality test, and the findings were shown in Table 8. The findings revealed a unilateral causality from intellectual property rights and FDI inflows to high technology exports, and from FDI inflows to intellectual property rights. 
The intellectual property rights and $R \& D$ expenditures have become the crucial factors on the way to knowledge-based economy as of 1980s. An effective system of intellectual property rights in terms of patents, copyrights, and trademarks encourages the firms to invest in $R \& D$ for innovative activities depending on the country development level and in turn foster the economic growth through enhancing the productivity and high-tech export. So high-tech export can be seen a significant indicator of the property rights system and R\&D expenditures. In this regard, it is theoretically expected that both property rights and R\&D expenditures affect the high-tech export positively.

Table 8

Dumitrescu and Hurlin (2012) causality test

\begin{tabular}{|c|c|c|c|}
\hline Null Hypothesis: & W-Stat. & Zbar-Stat. & Prob. \\
\hline DPRIGHT $\nrightarrow$ DHIGHTECH & 6.16615 & 3.45582 & 0.0005 \\
\hline DHIGHTECH $\nrightarrow$ DPRIGHT & 1.92173 & -0.62459 & 0.5322 \\
\hline DRD $\nrightarrow$ DHIGHTECH & 3.00446 & 0.41630 & 0.6772 \\
\hline DHIGHTECH $\nrightarrow$ DRD & 1.06580 & -1.44745 & 0.1478 \\
\hline DFDI $\nrightarrow$ DHIGHTECH & 4.62539 & 1.97459 & 0.0483 \\
\hline DHIGHTECH $\nrightarrow$ DFDI & 2.64834 & 0.07394 & 0.9411 \\
\hline DRD $\nrightarrow$ DPRIGHT & 2.09370 & -0.45927 & 0.6460 \\
\hline DPRIGHT $\nrightarrow$ DRD & 1.37592 & -1.14932 & 0.2504 \\
\hline DFDI $\nrightarrow$ DPRIGHT & 7.13706 & 4.38921 & 1.E-05 \\
\hline DPRIGHT $\nrightarrow$ DFDI & 3.47575 & 0.86938 & 0.3846 \\
\hline
\end{tabular}

Source: compiled by the authors

The short run interaction between property right protection and high technology export was studied by causality analysis, and the analysis results disclosed that protection of property right had a significant effect on high technology export. Furthermore, the long run impact of property right protection on high technology export was explored by cointegration test, and test results disclosed that property right protection made a positive significant protection to the high technology export in most of the countries in the long run. Our findings about the nexus between property rights protection and high technology export compromised with the relevant empirical literature. The empirical studies by Liu \& Lin (2005), Ivus (2008), Liu (2016), and Mrad (2017) discovered that protection of property rights positively affected the high-tech export in parallel with our findings.

$\mathrm{R} \& \mathrm{D}$ expenditures also can promote high technology export through raising the high technology products. Our short run analysis disclosed that R\&D expenditures had no significant impact on high technology export, but it considerably contributed to the high technology export in the long run. The impact of R\&D expenditures on the high technology export was found to be much higher than the property rights protection is. Our findings were consistent of theoretical considerations by Posner (1961), Vernon (1966), and endogenous growth theories. Furthermore, Braunerhjelm \& Thulin (2008), Kiliç et al. (2014), and Çetin (2016) reached the similar findings in the related literature.

The theoretical considerations including dependency theory and industrialization theory differ on the economic effects on FDI inflows. However, the impact of inward FDI inflows on the high-tech export can be varied depending on FDI type, human capital quality, economic and technological development level of the countries. In this context, the technological spillover level of FDI inflows is the main determinant in the interaction between FDI-high-tech export depending on FDI type, human capital quality, economic and technological development level of the countries. The countries with higher 
qualified human capital and higher development level generally attract technological FDI inflows, and this improves the innovation and technological capacity of the countries. Other types of FDI inflows may negatively affect the technological development of the countries by limiting them with traditional production. In our study, the short run causality analysis revealed that FDI inflows had a significant effect on high technology export in the short run. However, FDI inflows negatively affected high technology export in overall panel and most of the countries. The finding can be resulted from type of FDI inflows, human capital quality, or economic development level of the countries. The relevant empirical literature also has stayed inconclusive on the effect on FDI inflows on high technology exports (e.g. see Gokmen \& Turen, 2013; Bakirci et al., 2017).

\section{CONCLUSION}

A great number of countries have changed their strategy to the export-led industrialization from import substituting industrialization to raise the share of the goods with high added-value in the export. In this context, many institutional, legal, economic, political, and cultural factors have been documented as the drivers of the high-tech export. In this regard, intellectual property rights, R\&D expenditures, and FDI inflows are theoretically expected to raise the volume of high-tech export by the countries depending on the country-specific characteristics.

The study empirically explored the effect on intellectual property rights and $R \& D$ expenditures together with FDI inflows on high-tech export by EU transition economies over the 2000-2016 period through panel causality and cointegration analysis. The long-run econometric analyses revealed that both intellectual property rights and R\&D expenditures affected the high technology export positively in the long term, while FDI inflows negatively affected the high technology export in overall panel in the short run. But the effect of R\&D expenditures on high technology export was far more rather than the effect of property rights and FDI inflows. However, the causality analysis revealed a unilateral causality from intellectual property rights and FDI inflows to high technology export, but R\&D had no significant effect on the high-tech export in the short term.

The relevant theoretical and empirical literature revealed that an optimal protection of intellectual property rights improved the technological development by encouraging the firms for R\&D expenditures and in turn raised the high-tech export. However, the impact of R\&D expenditures on the high-tech export can be much larger considering the direct and indirect effects. Furthermore, the current human and physical capital is determinative for the effect on both intellectual property rights and R\&D expenditures on the high-tech export. In the study, we revealed that property rights positively affected the high technology export in Bulgaria, Estonia, Hungary, Lithuania, Poland, and Slovak Republic. However, R\&D expenditures had a positive influence on high technology export in Croatia, Czech Republic, Hungary, Latvia, Lithuania, Poland, Romania, and Slovak Republic, but the coefficients varied considerably among the countries depending on the aforementioned country-specific characteristics. Lastly, the impact of inward FDI inflows on the high-tech export can be varied depending on FDI type, human capital quality, economic and technological development level of the countries. The countries with higher qualified human capital and higher development level generally attract technological FDI inflows, and this improves the innovation and technological capacity of the countries. Other types of FDI inflows may negatively affect the technological development of the countries by limiting them with traditional production. So the negative effect of FDI inflows on high-tech export in Bulgaria, Czech Republic, Hungary, Latvia, Romania, and Slovak Republic can be attributed to the country specific characteristics.

Consequently, an optimal protection by the system of intellectual property rights and R\&D expenditures are the significant complementary of export-led growth. Furthermore, higher human capital 
quality and physical capital are supposed to draw the technological FDI inflows. In this regard, future studies can be focused on the FDI-high-tech export for the countries with different levels of economic and technological development.

\section{REFERENCES}

Bakirci, F., Heupel, T., Kocagoz, O., \& Ozen, U. (2017). German-Turkish perspectives on IT and innovation management: challenges and approaches. Wiesbaden: Springer.

Belay, S. (2005). Determinants of levels of high technology exports. An empirical investigation. Advances in Competitiveness Research, 13(1), 64-79.

Braunerhjelm, P., \& Thulin, P., (2006). Can Countries Create Comparative Advantages? Centre of Excellence for Studies in Science and Innovation (CESIS), Electronic Working Paper Series, Working Paper No. 61.

Breusch, T. S., \& Pagan, A. R. (1980). The Lagrange Multiplier Test and Its Applications to Model Specification Tests in Econometrics. Review of Economic Studies, 47(1), 239-253.

Çetin, R. (2016). Yeni Sanayileșen Ülkelerde AR-GE Harcamaları ve Yüksek Teknoloji Ürünü İhracatı Arasındaki İlişkinin Panel Veri Analizi Yöntemi ile İncelenmesi. İktisat Fakültesi Mecmuasi, 66, 30-43.

Dumitrescu, E., \& Hurlin, C. (2012). Testing for Granger non-causality in heterogeneous panels. Economic Modelling, 29(4), 1450-1460. DOI: 10.1016/j.econmod.2012.02.014

Dzemydaite, G., Dzemyda, I., \& Jurgelevičius, A. (2012). Evaluation of the implementation of national export development strategy: case study of the Republic of Lithuania. Intellectual Economics, 6 (1/13), 776-797.

Eberhardt, M., \& Teal, F. (2010). Productivity analysis in global manufacturing production. Discussion Paper 515, Department of Economics, University of Oxford. http://www.economics.ox.ac.uk/research/WP/pdf/paper515.pdf.

Falk, M. (2009). High-tech exports and economic growth in industrialized countries. Applied Economics Letters, 16 (10), 1025-1028. doi:10.1080/13504850701222228

Fraser Institute (2019). Economic Freedom. Retrieved from: https://www.fraserinstitute.org/economicfreedom $/$ dataset?geozone $=$ world \&year $=2016 \&$ page $=$ dataset $\&$ min $-y e a r ~=2 \&$ max - year $=0 \&$ filter $=0$

Gokmen, Y., \& Turen, U. (2013). The determinants of high technology exports volume: a panel data analysis of EU 15 countries. International Journal of Management Economic and Social Sciences, 2(3), 217- 232.

Guravsar Gocke, S., Karatepe, S., \& Karagoz, M. (2010). The impact of RevD intensity on high tech exports. Retrieved from: https://www.academia.edu/37174504/The Impact of R and D Intensity on High Tech Exports

Hwang, H., Wu, J. Z., \& Yu, E. S. H. (2016). Innovation, imitation and intellectual property rights in developing countries. Review of Development Economics, 20(1), 138-151.

Im, K. S, Pesaran, M. H., \& Shin, Y. (2003). Testing for unit roots in heterogeneous panels. Journal of Econometrics, 115(1), 53-74. doi:10.1016/S0304-4076(03)00092-7

Ivus, O. (2008). Do stronger intellectual property rights raise high-tech exports to the developing world? Retrieved from: https://econ.ucalgary.ca/manageprofile/sites/econ.ucalgary.ca.manageprofile/files/unitis/publications/16234130/IPR emp Oct2008.pdf

Kabaklarli, E., Duran, M. S., \& Ucler, Y. T. (2018). High-tech technology exports and economic growth: panel data analysis for selected OECD countries. Forum Scientiae Oeconomia, 6(2), 47-60. doi:10.23762/FSO_VOL6NO2_18_4

Kilıç, C., Bayar, Y., \& Özekicioğlu, H., (2014). Araştırma Geliştirme Harcamalarının Yüksek teknoloji Ürün İhracatı Üzerindeki Etkisi: G-8 Ülkeleri İçin Bir Panel Veri Analizi. Erciyes Üniversitesi İktisadi ve İdari Bilimler Fakültesi Dergisi, 44, 115-130.

Kizilkaya, O., Ay, A., \& Sofuoğlu, E. (2016). The determinants of high technology product export in brict countries: an econometric approach. Global Journal on Humanities \& Social Sciences, 4, 112-117.

Lall, S. (2000). The technological structure and performance of developing country manufactured exports: 19951998. Oxford Development Studies, 28(3), 337-369.

Lin, J., \& Linkoln, W. (2018). Intellectual property rights affect the pattern of trade. Retrieved from: https://voxeu.org/article/intellectual-property-rights-affect-pattern-trade

Liu, W. H., \& Lin, Y. C. (2005). Foreign patent rights and high-tech exports: evidence from Taiwan. Applied Economics, 37 (13), 1543-1555. doi: 10.1080/00036840500173155 
Mark, N. C., Ogaki, M., \& Sul, D., (2005). Dynamic Seemingly Unrelated Cointegrating Regressions. Review of Economic Studies, 72(3), 797-820.

McCoskey, S., \& Kao, C., (1998). A Residual-based Test of the Null of Cointegration in Panel Data. Econometric Reviews, 17(1), 57-84. doi:10.1080/07474939808800403

Mehrara, M., Seijani, S., \& Karsalari, A.R. (2017). Determinants of high-tech export in developing countries based on Bayesian model averaging. Zbornik radova Ekonomskog fakulteta u Rijeci, 35(1), 199-215. doi:10.18045/zbefri.2017.1.199

Mitic, B., \& Ivic, M. (2016). The impact of foreign direct investment on export performance: case of European transition economies. Independent Journal of Management and Production, 7(3), 771-785. doi: 10.14807/ijmp.v7i3.44

Mrad, F. (2017). The effects of intellectual property rights protection in the technology transfer context on economic growth: the case of developing countries. Journal of Innovation Economics and Management, 2(23), 33-57.

Pesaran, M. H. (2004). General diagnostic tests for cross section dependence in panels. University of Cambridge, Working Paper, CWPE 0435.

Pesaran, M. H. (2007). A simple panel unit root test in the presence of cross-section dependence. Journal of Applied Econometrics, 22(2), 265-312.

Pesaran, M. H., (2006). Estimation and inference in large heterogeneous panels with a multifactor error structure, Econometrica, 74(4), 967-1012. doi: 10.1111/j.1468-0262.2006.00692.x

Pesaran, M. H., Ullah, A., \& Yamagata, T. (2008). A bias-adjusted LM test of error cross-section independence. Econometrics Journal, 11, 105-127.

Pesaran, M. H., \& Yamagata, T. (2008). Testing slope homogeneity in large panels. Journal of Econometrics, 142, $50-93$.

Posner, M.V. (1961). International Trade and Technical Progress. Oxford Economic Papers, 13, 323-341,

Sandu, S., \& Ciocanel, B. (2014). Impact of R\&D and innovation on high-tech export. Procedia Economics and Finance, 15, 80-90. doi: https://doi.org/10.1016/S2212-5671(14)00450-X

Srholec, M. (2005). High-tech exports from developing countries: a symptom of technology spurts or statistical illusion? Review of World Economics, 143(2), 227-255. doi: 10.1007/s10290-007-0106-z

Taplin, R., \& Novak, A. Z. (2010). Intellectual property, innovation and management in emerging economies. London: Routledge.

Tebaldi, E. (2011). The determinants of high-technology exports: A panel data analysis. Atlantic Economic Journal, 39(4), 343-353. doi: 10.1007/s11293-011

United Nations Conference on Trade and Development (2019). World Investment Report: Annex Tables. Retrieved from: https://unctad.org/en/pages/diae/world\%20investment \%20report/annex-tables.aspx (10.01.2019)

Ustabas, A., \& Ersin, O. O. (2016). The effects of R\&D and bigh technology exports on economic growth: A comparative cointegration analysis for Turkey and South Korea. Retrieved from: https://avekon.org/papers/1475.pdf

Vasa, L. (2012). The European Paradox and the Innovation Activity of the Hungarian SME Sector. Conference Proceedings Chapters, in: Kiril Todorov \& Atanas Damyanov (ed.), European Entrepreneurship as an Engine for PostCrisis Development - Challenges and Opportunities. Proceedings of the International Conference, 8-10, 1(127), 131-148.

Vernon, R. (1966). International Investment and International Trade in the Product Cycle. Quarterly Journal of Economics, 80, 190-207.

Westerlund, J., \& Edgerton, D. (2007). A panel bootstrap cointegration test. Economics Letters 97(3), 185-190. doi:10.1016/j.econlet.2007.03.003

World Bank (2019a). High-technology exports (\% of manufactured exports). Retrieved from https://data.worldbank.org/indicator/TX.VAL.TECH.MF.ZS

World Bank (2019b). Research and development expenditure (\% of GDP). Retrieved from https://data.worldbank.org/indicator/GB.XPD.RSDV.GD.ZS

World Bank (2019c). Foreign direct investment, net inflows (\% of GDP). Retrieved from https:// data.worldbank.org/indicator/BX.KLT.DINV.WD.GD.ZS

Xing, Y. (2012). The People's Republic of China's high tech exports: myth and reality. ADBI Working Paper no. 5055, Tokyo: Asian Development Bank Institute. Retrieved from https://www.adb.org/sites/default/files/publication/156212/adbi-wp357.pdf 